\title{
QS 9000 AS A STEPPING STONE TO TQM A STUDY IN \\ INDIAN AUTO COMPONENT INDUSTRY
}

\section{Dr. Lakshmi Jagannathan*}

\begin{abstract}
Post liberalization in the nineties, Indian economy transformed with an influx of multinational automotive companies into India. The entry of these foreign auto companies changed quality standards and impacted the complexity of the parts required by OEMs. The component manufacturers embraced the practices of Total Quality Management (TQM ). Total Productive Maintenance (TPM) and lean manufacturing practices. The journey towards TQM was propelled by the vision to become global. One of the strategies that Indian component manufacturers adopted to become part of the global value chain was the QS 9000 certification. This paper is an attempt to understand the impact of QS 9000 certification on TQM implementation. It ascertains the role that QS 9000 certification plays in transforming organizations with respect to the critical success factors of TQM implementation. The analysis is based on data collected for a specific study on TQM among auto component manufacturers in Chennai. Data pertaining to the level of critical success factors was examined prior to and post certification, to draw conclusions.
\end{abstract}

\section{Introduction}

Quality is one of the important critical success factors to achieve competitiveness in organizations (Khanna et al., 2003 ). One of the major reasons for the dismal performance of the Indian automobile sector in world markets was the lack of effective quality management systems (Khanna et al., 2002). The success of the Japanese automobile industry in the late eighties is owed largely to the adoption of quality improvement methodologies, including TQM. Since then TQM has played a major role in transforming manufacturing and service organizations world over. It is therefore imperative for the Indian automobile sector to understand and analyse the complex interactions and the dynamics of factors affecting TQM, and the outcome of TQM over a longer time horizon. This will allow the Indian auto component industry to evolve a strategic plan through the integration of all the identified dominant factors interacting or being acted on.

\section{QS 9000 as a tool for TQM implementation}

QS 9000 is the automotive quality technical and managerial standard developed by the Automotive Industry Action Group (AIAG) in conjunction with DaimlerChrysler, Ford and General Motors (Chrysler Corporation et al., 1998). The goal for quality system requirements QS 9000 is the

*Assistant Professor Department of Management Studies Dayananda Sagar College of Engineering, Bangalore 
development of fundamental quality systems that provide for continuous improvement, emphasizing defect prevention and the reduction of variation and waste in the supply chain (Chrysler Corporation et al., 1998).

The QS 9000 quality system is comprehensive and addresses all phases of product and part development, engineering, manufacturing, storage, shipping and delivery. It standardizes the procedures applicable to all the above stages and making them transparent to everyone in the organisation (as opposed to selected few experts working in the area). This is the quality system of choice in order to be competitive in the ever changing automotive world (Jodoin, 1998). It is a vehicle to continuously improve the quality of product in all phases from development through delivery and as a result improve the competitive position of the organisation. Hence, the QS 9000 project can be viewed in a broad strategic context as an important vehicle enabling the automotive manufacturers and suppliers to contain and reduce their costs and to increase their market share Evans et al . (1997).

The intent of the standard is to force automotive supplier organisations to build systems that prevent the occurrence of problems and allow for continuous improvement to prevent recurring problems. This characteristic forces organisations to transform their cultures towards total quality management (TQM) (Tom Bramorkski et al (2000). The manufacturers no longer compete based entirely on their own strengths disregarding where their parts are coming from and how good they are in terms of functional strengths. Instead they compete based on the strengths of the entire chain involving their own organizations and those of their suppliers. Transparent and harmonized requirements underlying the QS 9000 quality system make understanding and meeting the quality system requirements much easier for suppliers located anywhere in the world. QS 9000 provides a quality management system that focuses on continuous improvement, defect prevention, reduction of variation, reduction of waste in the supply chain with the objective of increasing customer satisfaction and reducing quality costs. These TQM elements foster the ideas of improved efficiency, delivery, improve company morale and enhance communication (Corrigan, 1994).

\section{TQM Framework for Auto Component Manufacturers}

A study was conceptualized in order to understand and assess if QS 9000 certification had any catalyzing effect on a firm's TQM journey. In order to understand the impact of this certification, a TQM framework was developed and empirically tested. Malcolm Balridge National Quality Award (MBNQA) criteria was taken as the basis for the proposed framework as it addressed the principal domains of TQM (Saraph.J.V , Benson G, \& Schroder.R.G. 1989, Anderson, Rungtusanatham and Schroeder, 1995). Brainstorming was done with TQM experts and an acceptance was obtained on the framework. 
The frame work consisted of enablers / critical success factors or drivers of the TQM initiative and the results / outcomes of TQM implementation (Fig 1 ). Critical Success Factors (CSFs) of TQM are latent variables, that cannot be measured directly (Ahire et al., 1996). The CSFs included for this study were based on research done by Saraph et al. (1989), Ahire et al (1996) and Anderson et al (1994). Measures were developed to represent manifestations of these CSFs .

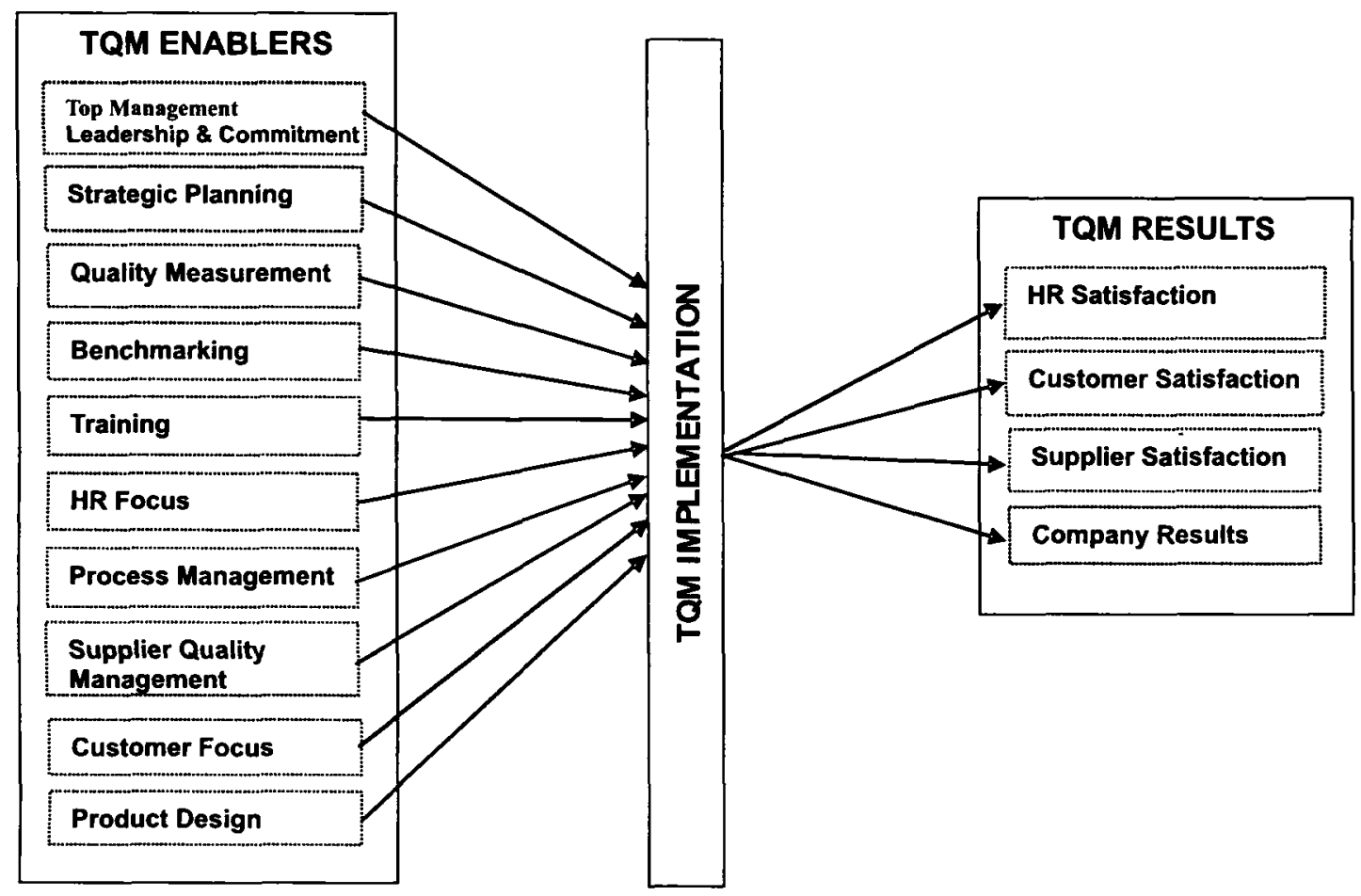

Fig 1 : Framework for TQM among auto component manufacturers

The identified critical success factors / enablers of TQM implementation were considered as the independent variables. The enablers being, Top Management Leadership \& Commitment, Strategic Planning, Quality Measurement, Benchmarking, Training, HR Focus, Process Management ,Supplier Quality Management, Customer Focus and Product Design. Results are the measures of the level of output and outcomes of TQM implementation. Results are emphasized in all the award models examined. It is observed that quality (in the form of high levels of customer satisfaction) is achieved through leadership driving strategic planning, keeping a focus on its people, customers, markets and suppliers and effectively managing the processes leading ultimately to better business results (Spitzer, 1995). The outcomes of TQM, i.e, Employee Satisfaction, Customer Satisfaction, Supplier Relationship and Operational performance were the dependent variables. 


\section{Research Methodology \& Hypothesis}

In order to understand the role of QS 9000 in driving TQM initiatives a study was done on QS 9000 certified auto component manufacturers. This was a study to understand the extent to which TQM principles have been adopted in QS 9000 or TS 16949 auto component manufacturing companies. The basic research question that this study aimed to address was "does QS 9000 help auto component manufacturing companies in their TQM journey?"

The primary hypotheses that would be tested in order to obtain an answer to the above research question were:

$\mathrm{H} 1$ : There is no significant difference in enablers of TQM , before and after QS 9000 certification.

$\mathrm{H} 2$ : There is no significant difference in outcomes of TQM , before and after QS 9000 certification.

\section{Respondents of the study}

This study on TQM implementation in certified Indian auto component industries was focused on auto component manufacturing companies in and around Chennai, Tamilnadu. Since Chennai occupied a formidable position contributing $35 \%$ of india's auto component production, it was chosen as the area of study ( www.acmainfo.com ). A list of QS 9000 / TS 19649 certified in and around Chennai was obtained from quality certifications bodies Bureau Veritas Quality International (BVQI) and Det Norse Veritas (DNV).After deliberations with TQM experts in the industry, it was decided that companies with more than one year of certification would be chosen for the study as they would be able to assess any impact of the quality certification on TQM in their organizations. Data was collected from 135 companies with a response rate of $32 \%$. The respondents for the survey were the quality managers and executives of Quality certified auto Component-manufacturing companies. The research instrument used for data collection was a structured questionnaire which was tested for both reliability and validity. Fieldwork was done from January to May 2005.

\section{Analysis of the results}

The means of two variables, that is, both the enablers and the outcomes prior and post certification were analyzed. The Paired samples $T$ test computed the difference between the two variables for each case, and tested if the average difference was significantly different from zero. This study used SPSS software package (ver. 13.0 ) to work out the correlation between the variables under study. The test was conducted for all the enablers and outcomes. The results are reported in Table 1.

The levels of all the enablers and the outcomes have significantly increased after QS 9000 certification (table 1). The role of top management in driving TQM efforts by involving in activities such as support for quality initiatives, involvement with senior managers, review of quality 
mechanism has increased after certification. Among all the enablers the top management leadership is of prime importance in driving TQM initiatives.(Johnson , 1993; Kane , 1992; Benson, Saraph and Schroeder , 1992 ). Post quality certification, the companies have started to keep customer in mind and strategically plan for both long term and shot term manufacturing capabilities \& advanced quality planning. Quality objectives have been clearly specified and been made measurable. Quality focused activities such as application of statistical tool for problem solving tools, calibration, practice of quality function deployment \& failure mode effect analysis seem to have increased after certification. After certification, companies have started to benchmark both internally and also with their competitors for better performance. Various measures have been analysed at company level to understand performance. Quality certification has improved training practices in companies with respect to planning and evaluation of effectiveness. Training is gaining ground as a strategic issue. Focus on team based work \& employee suggestion schemes are increasingly being adopted. Processes are defined to motivate employees and manage the work environment for achieve quality objectives. All key processes are continuously improved and controlled to meet defined customer expectations. Preventive maintenance and production flow analysis have been deployed in companies. Companies are empanelling vendors based on evaluation criterion. These 'supplier partners' team with the companies in meeting customer, government and safety requirements. Customer requirements regarding the product, packaging and labeling are documented. Designated personnel through effective communication maintain focus on internal and external customers. Emphasis on product design through prototypes, QC tools and computer aided design has increased. Measurements are done \& analysed at specific stages of design and development. Thus QS 9000 has an impact on all the critical success factors of TQM.

Table 1 Paired Samples T-test Mean Values

\begin{tabular}{|c|c|c|c|c|c|}
\hline \multirow{2}{*}{ No. } & \multirow{2}{*}{ Variable } & \multicolumn{2}{|c|}{ Mean $(N=135)$} & \multirow{2}{*}{$\begin{array}{c}\text { Mean } \\
\text { Difference } \\
\text { (absolute) }\end{array}$} & \multirow{2}{*}{$t$ - value } \\
\hline & & Before & After & & \\
\hline 1 & Top Management & 2.20 & 3.73 & 1.53 & $99.52^{* *}$ \\
\hline 2 & Strategic Planning & 1.61 & 2.71 & 1.10 & $35.09^{\star \star}$ \\
\hline 3 & Quality Measurement & 2.22 & 3.52 & 1.30 & $97.47^{\star \star}$ \\
\hline 4 & Benchmarking & 2.02 & 3.12 & 1.10 & $43.50^{\star \star}$ \\
\hline 5 & Training & 2.16 & 3.53 & 1.37 & $58.20^{\star \star}$ \\
\hline 6 & HR Focus & 2.19 & 3.83 & 1.64 & $61.47^{\star \star}$ \\
\hline 7 & Process Management & 2.53 & 4.10 & 1.57 & $80.43^{* *}$ \\
\hline 8 & Supplier Quality Management & 2.45 & 4.14 & 1.69 & $71.62^{\star *}$ \\
\hline 9 & Customer Focus & 2.32 & 3.98 & 1.66 & $61.04^{* \star}$ \\
\hline 10 & Product Design & 2.39 & 4.01 & 1.62 & $102.68^{\star *}$ \\
\hline 11 & Employee Satisfaction & 2.63 & 4.13 & 1.5 & $40.55^{\star \star}$ \\
\hline 12 & Customer Satisfaction & 2.45 & 4.31 & 1.86 & $59.42^{\star \star}$ \\
\hline 13 & Supplier Relationship & 1.51 & 4.33 & 2.82 & $69.61^{\star *}$ \\
\hline 14 & Operational Performance & 2.51 & 3.93 & 1.42 & $57.12^{\star \star}$ \\
\hline
\end{tabular}

${ }^{\star \star *}$ denotes t-significance at 0.01 level (2-tailed) 
With respect to outcomes of TQM, quality certification has improved all the variables of the outcomes. Supplier Satisfaction has the increased the most post certification and operational performance have the least impact. Employee satisfaction level seems to have increased with increased motivation and rewards for success. Respondents opine that customer satisfaction level has increased and they are able to respond to customers faster and better. With increased supplier satisfaction, it was felt that small number of high quality suppliers deliver consistent quality and are partners in business. Overall the company's operational performance in terms of productivity, throughput time, cycle time and market share have improved.

Since the mean difference in the levels of both the enablers and the outcomes have increased after certification, both the hypotheses $\mathrm{H} 1$ and $\mathrm{H} 2$ have been rejected. Thus it can be inferred that there is clearly a difference in the levels of critical success factors, before and after the certification. In other words, QS 9000 certification has an impact on TQM implementation among auto component manufacturers.

\section{Conclusion}

To improve their quality performance, companies should employ a broadened approach to integrate quality initiatives into the business strategy, improve the communications between the management and employees, encourage the use of teams to resolve quality issues, focus on preventive instead of reactive measures and reward / recognize employees for their efforts. Since QS 9000 is a technical standard and has an impact on the deliverables such as quality and delivery PPMs (Parts Per Million). To make the quality initiative more holistic, companies can integrate an Excellence model such as the Malcolm Baldridge Award Criteria in to the strategic planning process. Then the strategic focus will not only be on operations and technical aspects of the company, but also looks at leadership, long term planning, customer and market focus, information and analysis, human resource development and management, process management and business results. This comprehensive approach to business will prove to be a better indicator of long term business success. This study if done longitudinally will be able to assess the impact of the various forces, both internal and external to the organisation on TQM implementation.

Auto component manufacturing companies who have started off their quality journey with QS 9000 certification certainly see an improved level of TQM activities in their organisation. These companies can take this certification as a stepping stone to reach greater heights of business excellence. 


\section{REFERENCES}

1. Anderson, J.C., Rungtusanatham, M., Schroeder, R.G and Devaraj, S. (1995), "A path analytic model of a theory of quality management underlying the Deming management method: preliminary empirical findings",Decision Sciences, Vol.26 No5, September I October, pp.637-58

2. Chrysler Corporation, Ford Motor Company and General Motors Corporation (1998), Quality Systems Requirements, QS 9000, $3^{\text {rd }}$ ed, Automotive Industry Action Group , Southfield, MI, March.

3. Corrigan, J.P (1994), "Is ISO 9001 the path to TQM?", Quality Progress, Vol.27, pp. 33-6

4. Evans, J.R (1997), "Beyond QS 9000" , Production and Inventory Management Journal, Vol 38 No3, pp, 72-6

5. Khanna, V.K., Vrat, P., Shankar, R and Sahay, B (2002), “Developing casual loop relationship for a TQM index for the Indian automobile sector", work study, Vol.51 No 7 , PP 364- 73

URL:

( www.acmainfo.com ) - Home page of Auto component Manufacturers Association 